\title{
Resistance Genes in Global Crop Breeding Networks
}

\author{
K. A. Garrett, ${ }^{\dagger}$ K. F. Andersen, F. Asche, R. L. Bowden, G. A. Forbes, P. A. Kulakow, and B. Zhou
}

First and second authors: Plant Pathology Department, Emerging Pathogens Institute, and Institute for Sustainable Food Systems, University of Florida, Gainesville 32611; third author: School of Forest Resources and Conservation and Institute for Sustainable Food Systems, University of Florida, Gainesville; fourth author: United States Department of Agriculture-Agricultural Research Service Hard Winter Wheat Genetics Research Unit, 4008 Throckmorton Hall, Kansas State University, Manhattan 66506; fifth author: International Potato Center, Lima, Peru; sixth author: International Institute of Tropical Agriculture, Ibadan, Nigeria; and seventh author: International Rice Research Institute, Manila, Philippines.

Accepted for publication 25 June 2017.

\begin{abstract}
Resistance genes are a major tool for managing crop diseases. The networks of crop breeders who exchange resistance genes and deploy them in varieties help to determine the global landscape of resistance and epidemics, an important system for maintaining food security. These networks function as a complex adaptive system, with associated strengths and vulnerabilities, and implications for policies to support resistance gene deployment strategies. Extensions of epidemic network analysis can be used to evaluate the multilayer agricultural networks that support and influence crop breeding networks. Here, we evaluate the general structure of crop breeding networks for cassava, potato, rice, and

wheat. All four are clustered due to phytosanitary and intellectual property regulations, and linked through CGIAR hubs. Cassava networks primarily include public breeding groups, whereas others are more mixed. These systems must adapt to global change in climate and land use, the emergence of new diseases, and disruptive breeding technologies. Research priorities to support policy include how best to maintain both diversity and redundancy in the roles played by individual crop breeding groups (public versus private and global versus local), and how best to manage connectivity to optimize resistance gene deployment while avoiding risks to the useful life of resistance genes.
\end{abstract}

Epidemiological network analysis offers an important perspective in plant pathology, and is becoming a standard tool for understanding the spread of disease (Moslonka-Lefebvre et al. 2011; Shaw and Pautasso 2014). Epidemic network analysis provides insights into not only disease spread between individual pairs of locations but also the cumulative effects of connections between locations that influence regional processes and determine whether regional disease management is successful. Multilayer networks can be used to integrate understanding of system components such as how the spread of information influences the spread of disease (Buddenhagen et al. 2017; Garrett 2012; Hernandez Nopsa et al. 2015). Another multilayer network that drives epidemics and the potential for their successful management is the movement of disease and pest resistance genes through the components of global and regional crop breeding networks.

This article addresses the global crop breeding network, the global set of crop breeder groups, and the links formed between them by the movement of genes in crop germplasm, which is a major factor in determining the global distribution of crop genotypes and phenotypes (Fig. 1). Although gene networks within individual organisms are a growing research focus, the global crop breeding network has received limited analysis from a systems standpoint, despite its key role in food security during global change (Fowler and Hodgkin 2004). resistance genes offer one of the most sustainable approaches to management of diseases and arthropod pests (Boyd et al. 2013; Byerlee and Dubin 2009), although resistance genes have variable lifespans, some lasting only a few seasons while others remain effective for decades (McDonald and Linde 2002). In some cases, the

†Corresponding author: K. A. Garrett; E-mail: karengarrett@ufl.edu

*The $\boldsymbol{e}$-Xtra logo stands for "electronic extra" and indicates that one supplementary file is published online.

Copyright (C) 2017 The Author(s). This is an open access article distributed under the CC BY 4.0 International license. deployment of resistance genes can be coordinated in an effectively structured crop breeding network to decrease the likelihood that pathogen or pest populations evolve to overcome resistance. When new germplasm is introduced into a region, it may bring desirable traits (increased yield, drought resistance, or vigor) but may inadvertently introduce susceptibility to endemic pathogens (or even introduce new pathogens), resulting in new disease outbreaks. Alternatives to host plant resistance for disease and pest management often have economic or environmental costs: use of foliar and seedapplied pesticides may affect nontarget species, and cultural practices such as increased tillage may increase soil erosion. These alternatives may also be too expensive, especially for smallholder farmers in developing countries. Host plant resistance, on the other hand, generally has little additional cost beyond the cost of seed.

Several components of global change pose new challenges for the development of effective crop varieties (Fig. 1). With climate change, the geographic distribution of high-risk regions for diseases and pests will shift; there will be higher uncertainty about risk, influencing decision-making; and higher levels of risk than previously observed may occur (Bebber et al. 2013; Chapman et al. 2012; Garrett et al. 2013; Pautasso et al. 2012). With increasing global trade and transportation, pathogen and pest invasions will accelerate. Both land use change and climate change are likely to decrease in situ conservation of crop wild relatives that are a source of new resistance genes (Dempewolf et al. 2014; Jarvis et al. 2008). Crop breeding itself is undergoing dramatic changes. Gene editing technologies and societal responses to them will have major impacts on crop breeding in the near future. The steady privatization of crop breeding systems (Marden and Godfrey 2012) has important and little-studied implications for the deployment of resistance genes, and how seed and information are shared in the crop breeding network. Although public breeding groups have often had clear incentives to share resistance genes with other breeding groups, private breeding groups may have different profiles of incentives for and against sharing germplasm. Private breeding groups may also be commercially aligned with groups that develop pesticides and, in some cases, 
overall profits to a commercial entity may be higher from investments in research and development $(R \& D)$ for pesticides than for resistance genes. A lack of resistance may also incentivize farmers to buy seed more frequently to avoid the buildup of seedborne disease, providing another potential conflict of interest. As a higher proportion of crop breeders become private crop breeders, there also may be fewer crop breeders with the professional responsibility to provide a public critique of global crop breeding systems. Conversely, private crop breeding groups may be prepared to invest more in the development and deployment of resistance genes, and generally have access to larger financial resources because they can utilize capital markets if they can demonstrate expected profitability.

The science of complex adaptive systems (CAS) conceptualizes systems of agents (for example, crop breeders) who can act independently, and whose actions in aggregate produce system outcomes (Levin 1998; Miller and Page 2007). This article draws on theory related to CAS and the implications of such a structure for resilience strategies. The objectives of this article are to (i) develop a framework for evaluating crop breeding networks for the spread and deployment of resistance genes, and the resulting effects on global crop epidemics; (ii) evaluate a representation of the global crop breeding networks for four major food crops: cassava, potato, rice, and wheat; and (iii) draw on theory about system resilience to inform regional and global policies and identify research priorities for improving the deployment of resistance genes.

Resistance genes in crop breeding networks as a CAS. CAS are systems that have a set of defining traits (Fig. 1) such as hierarchies, nonlinearity, diverse identities of system agents who make choices based on their own "models" about their perceived environment, and components that can be aggregated to function differently in response to environmental stimuli (Holland 1995; Levin 1998). This set of traits may allow systems to adapt as a whole to perform aggregate functions better. However, if the incentives and decision-making models that drive agents' choices do not function well (McRoberts et al. 2011), the system as a whole may not function well, either. Conceptualizing systems as CAS can facilitate analysis of system traits that are more difficult to understand from a reductionist approach (Meadows and Wright 2008; Puettmann et al. 2013).

Crop breeding networks, especially considered in terms of the multilayer networks associated with them (Fig. 1), have all the traits associated with CAS. Individual crop breeding groups decide what resistance genes they will exchange with other breeding groups, and what resistance genes they will include in varieties they release. In some cases, key genes will be well studied and defined, potentially with markers available for marker-assisted selection (MAS). In other cases, unknown and uncharacterized resistance genes may be exchanged and deployed, often by chance, as breeders pursue the development of high-yielding cultivars. An aggregate outcome of individual decisions about exchange of genes is the global geographic distribution of deployed major resistance genes and quantitative trait loci (QTLs), and the degree to which the genes function effectively to reduce disease and support crop productivity. In addition to crop breeders, the crop breeding system includes other actors in a number of linked networks (Fig. 1). Actors involved in in situ and ex situ conservation of crop wild relatives, land races, and crop germplasm make decisions about which genes are conserved, and provide source material for prebreeding programs. These choices are influenced by international policies, such as the International Treaty on Plant Genetic Resources for Food and Agriculture (Esquinas-Alcázar 2005). Actors in prebreeding programs decide which resistance genes will be included in novel genetic material available as elite breeding lines to breeding programs. Actors in breeding programs decide which genes to include in the development of commercial varieties, including which combinations of (known or unknown) genes to deploy. These decisions are generally driven by market demand for certain types of resistance, and by policies that may influence which genes are available for deployment. Agents in seed systems decide which varieties to make available in sufficient numbers for planting, and how much care to take in avoiding the risk of pathogen and pest spread with seed. Farmers decide which of these varieties to grow and how to manage diseases and pests (McRoberts et al. 2011; Mills et al. 2011). The influence of these decisions on epidemics is driven by the resulting networks of pest and disease movement (Jeger et al. 2007; Shaw and Pautasso 2014). Feedback based on information about the most important recent epidemics and outbreaks then influence crop breeders' decisions about priorities for incorporating resistance (Garrett 2012). The connectivity of resistance gene deployment in the landscape helps to determine how severe a given disease is regionally and globally, and the likelihood of pathogen or pest evolution to overcome resistance, where useful patterns of resistance deployment may provide large-scale benefits in breaking the connectivity of landscapes (Margosian et al. 2009) comparable to smaller-scale benefits from within-field cultivar mixtures (Mundt 2002; Skelsey et al. 2005). Any trait, such as drought tolerance, would have a system of feedback based on whether farmers perceived the varieties incorporating the trait to be good choices. Epidemics have the additional feature that the good or bad disease management of

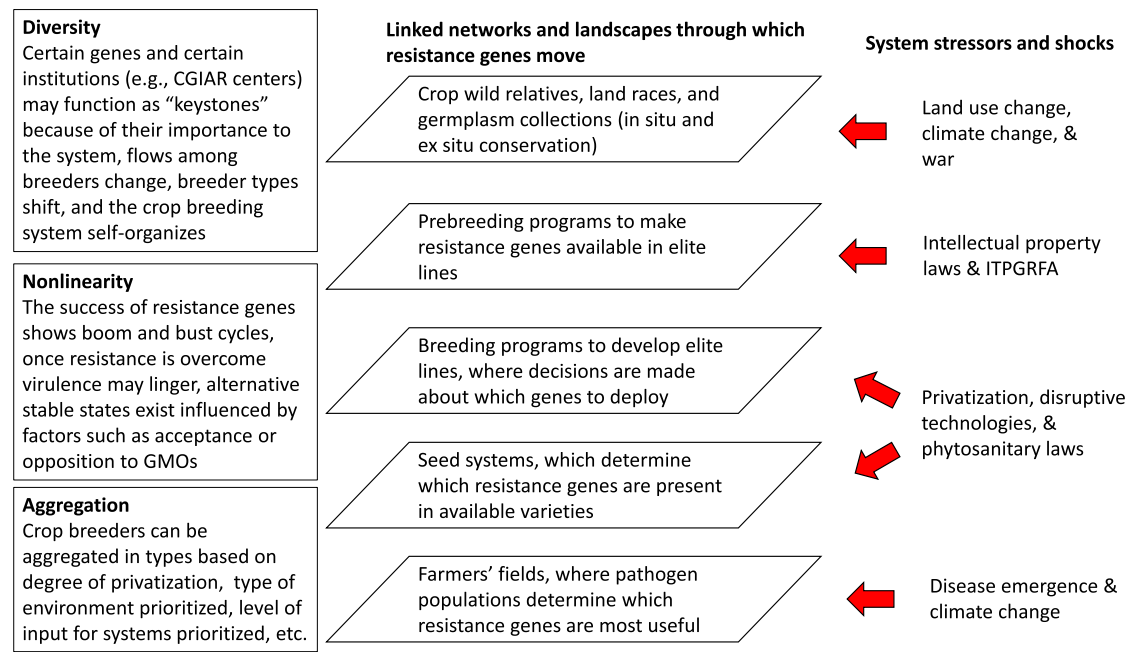

Fig. 1. System of resistance gene deployment, including (left) characteristics of the system that make it a complex adaptive system and (right) shocks and stressors to which the system must adapt. ITPGRFA = International Treaty on Plant Genetic Resources for Food and Agriculture, and GMOs = genetically modified organisms. 
neighbors will influence how well a farmer's own management choices play out. Each actor tends to make decisions to optimize their portion of the system.

The crop breeding network as a whole helps to determine what epidemics occur and how severe they are, epidemics provide feedback for decision-making by crop breeders, and the system as a whole responds to a set of challenging pulse and press stressors and shocks (Fig. 1). The multilayer network includes a range of connected components that are self-organized to a great extent, in which agents have different incentives depending on organizational structure (e.g., public versus private and local versus global). The structure of networks within a given layer, such as the crop breeding network layer, indicates some strengths and vulnerabilities of that layer and, thus, of the other layers linked to it (Fig. 2). The layered networks adapt to new scenarios such as emerging diseases and climate change, and there are many uncertainties about the success of the systems and of different candidate strategies for gene deployment regulation. As breeding programs rely more on genomic selection and prediction of phenotype based on genotype and less on breeder's visual selection across a broad range of testing locations, this may result in loss of resistance that would have been selected for naturally in early screening phases (Heffner et al. 2009). In addition to the movement of genetic material, the associated movement of information about crop phenotypes and information about the progress of epidemics or infestations are key system components (Deans et al. 2015; Garrett 2012).

\section{MATERIALS AND METHODS}

Modeling crop breeding networks. We evaluated the structure of global crop breeding networks for four major food crops: cassava, potato, rice, and wheat. We used expert elicitation (ThomasSharma et al. 2017) to estimate the network structures, beginning with the number of crop breeding groups that fall in each type of regional or international category, public or private, using a survey instrument designed for this purpose (Supplementary File S1). Following the general structure of an exponential random graph model (ERGM) (Robins et al. 2007), we estimated the probability of a directed link between any two categories of crop breeding groups over the last 5 years. Expert elicitation provides a useful alternative source of information when empirical data are not available, although it is subject to sources of bias and variability (Thomas-Sharma et al. 2017), such as differences in how experts might "lump" or "split" crop breeding groups when defining network nodes. In addition to the expertise in our group, we collected expert estimates about the structure of these global crop breeding networks from personnel in our respective institutions with direct experience with each crop species. These expert estimates can be interpreted as representing the actual networks in a probabilistic sense, such that the network representations illustrate the general structure of global crop breeding networks. We focus on current forms of genetic material exchange over the last 5 years with the understanding that historical movement of genes was primarily from crop and pathogen centers of origin (Thormann et al. 2015). The general numbers of crop breeding groups are represented by continent, and the probability of links (representing the flow of genetic material) between crop breeding groups are also represented. Individual nodes represent general types of crop breeding groups. Links among smaller crop breeding groups were generated randomly, according to the ERGM-like model developed through expert elicitation. These values were used to generate adjacency matrices plotted using the igraph package (Csárdi and Nepusz 2006) in the R programming environment ( $\mathrm{R}$ Core Team 2017).

In a more detailed analysis of the central star motif in the potato breeding network, we analyzed data from the International Potato Center (CIP) open-source Biomart database, which includes all breeding lines ordered from and distributed by CIP from 1979 through 2014. Distributions from CIP from 2010 to 2014 were analyzed and aggregated by receiving nation, maintaining the anonymity of individual institutions.

\section{RESULTS}

Lessons from four crop breeding systems. To illustrate the challenges that crop breeding networks must respond to, and the general nature of current networks, we summarized the resulting structure of four crop breeding networks central to global food security (Fig. 3) and current challenges that these crop breeding networks must address. An interactive model interface illustrates the outcomes when genes enter the network at different nodes (http://www.garrettlab.com/res-genes-cropbreeding-nets/). Standard metrics for describing networks can be applied to understand the structures and their implications (Table 1).

Network structures. Each of the crops presented here (potato, cassava, rice, and wheat) have large international breeding programs housed within the public-sector nonprofit international agricultural research centers (IARCs) that make up CGIAR. These centers have worked to develop modern varieties for low-income countries since the mid-20th century and continue to serve as major source nodes for new germplasm in crop breeding networks (Anderson et al. 1988; Evenson and Gollin 2003). For cassava (Fig. 3), there are two IARCs, the International Institute of Tropical Agriculture (IITA) and the International Center for Tropical Agriculture (CIAT), that are hub nodes providing national breeding programs in Africa, Asia, and South America with germplasm for selection and breeding purposes (Fig. 3). Similarly, public sector potato improvement programs (PIP) were initiated in many low-income countries in the mid- to late 20th century. CIP has been the primary hub node for distribution of resistance genes to these national programs, and provides breeding material to many breeding programs across the globe, as requested (Figs. 3 and 4). CIP breeders have mined native Andean potato genetic resources and have channeled genetic resources from other breeding programs. National PIP sometimes breed varieties but often only select from those distributed by CIP. Thus, CIP and national PIP can be seen as the primary decision makers about genes to be deployed for potato in these countries. Germplasm exchange for

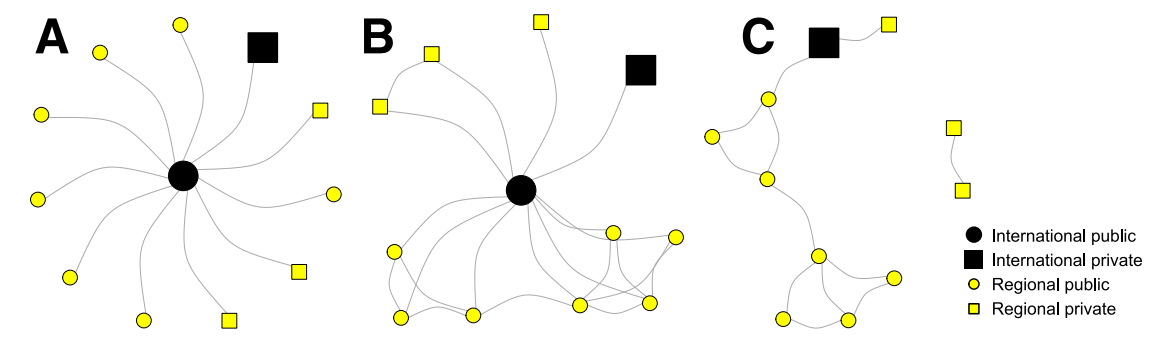

Fig. 2. Three scenarios for potential crop breeding network structures in a continent, illustrating costs and benefits. A, In this scenario, the crop breeding network is structured by a central international public breeding group. Many node pairs are linked but only due to the international public group hub. The international public group is the sole hub node (with high degree) and the sole bridge node (with high betweenness). B, In this scenario, in addition to the international public breeding group, there are multiple links within the continent. Again, many node pairs are linked, but now this connectivity is less dependent on the international public node. There is higher clustering. There are additional minor hub and bridge nodes, leading to a shorter average path length. $\mathbf{C}$, In this scenario, there is no central hub for the network, and it is split into multiple components without the clear star motif of scenarios A and B. Strong privatization of specific crops has the potential to create such a scenario. (Light nodes are regional groups, dark nodes are international groups, round nodes are public, and square nodes are private.) 
these crops has generally been one-way, with bidirectional information exchange assumed but often not fully realized (Figs. 3 and 4).

Cassava is unique in this analysis because there are currently very few private-sector breeding organizations. In contrast, potato, wheat, and rice are influenced by both local and multinational private breeding programs, and this influence varies regionally. For potato, there are many private breeding programs in high-income countries, but there is less influence of the private sector in low-income countries. Interestingly, in the case of rice, disease resistance has historically influenced the global rice breeding network structure. Major resistance genes for bacterial blight (BB) and rice blast (RB), caused by Xanthomonas oryzae pv. oryzae and Magnaporthe oryzae, respectively, have been introgressed into elite backgrounds by the public sector and these high-yielding varieties have been made publically available (Zhang 2007). This model has disincentivized multinational private companies from entering the rice seed business. However, the global rice breeding network may encounter a dramatic shift in coming years due to the introduction of hybrid rice technology. There are currently three CGIAR groups that work in rice breeding: the International Rice Research Institute (IRRI), the Africa Rice Center (AfricaRice), and CIAT, each with unique regional influence. The wheat breeding network is dominated by two large, international public organizations - the International Center for Wheat and Maize Improvement in Mexico (CIMMYT) and the International Center for Agricultural Research in the Dry Areas (ICARDA) - as well as several private multinational companies that each have large germplasm pools (Fig. 3). Some countries also have extensive national breeding programs with germplasm that is shared globally, such as the United States Department of Agriculture Germplasm Resources Information Network (GRIN).

Each crop breeding network exhibits high modularity (Fig. 3; Table 2), indicating that there is an inherent community structure. Each network has a higher likelihood of links occurring within

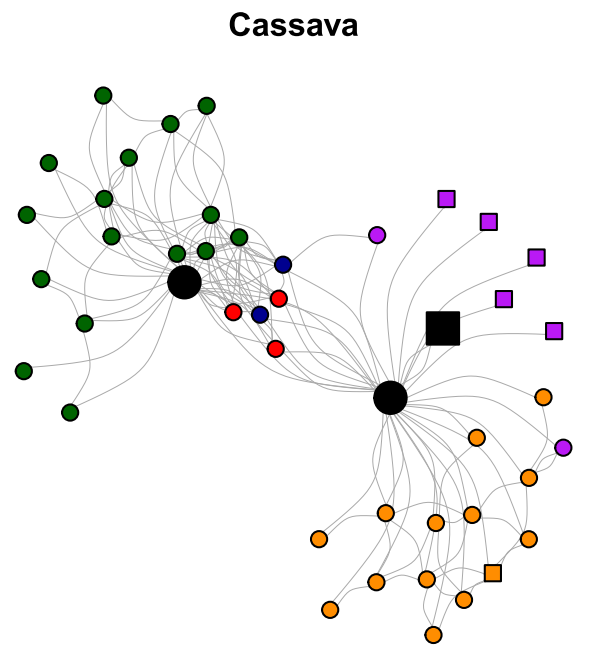

Rice

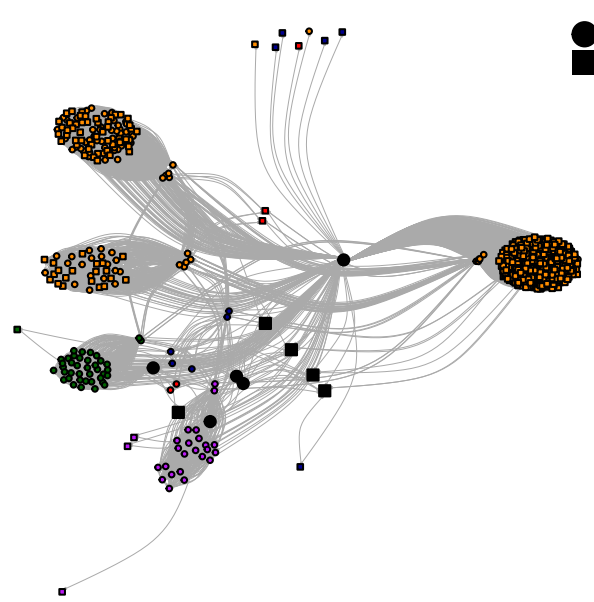

Potato

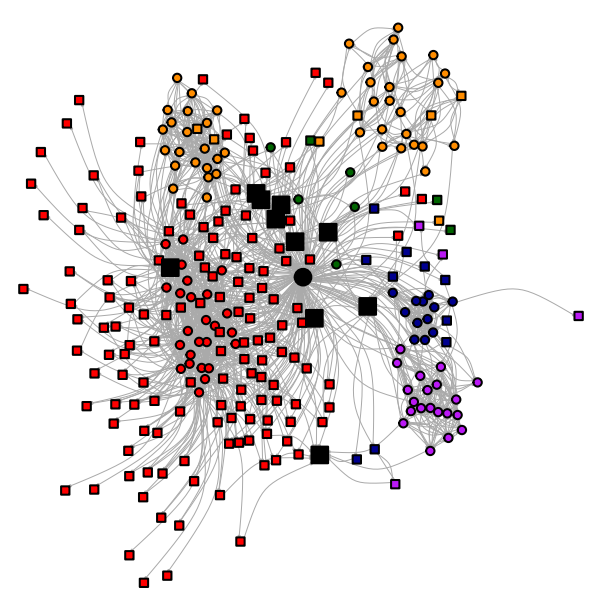

Wheat

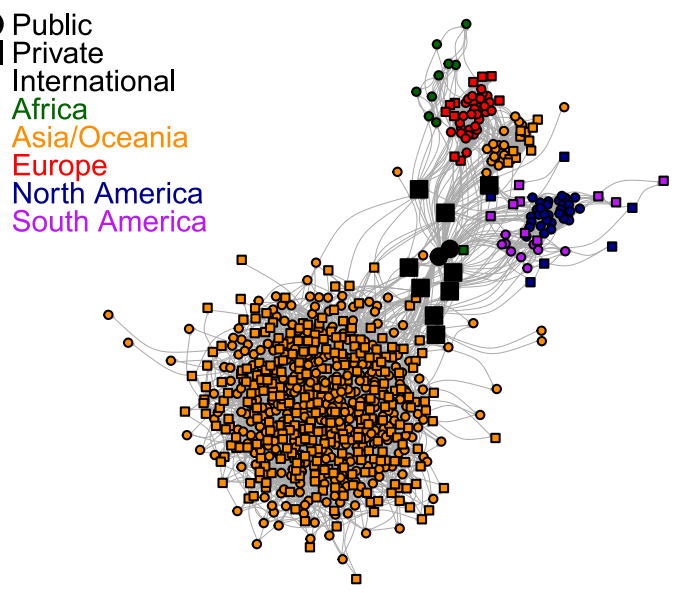

Fig. 3. Schematics of crop breeding networks for the movement of resistance genes. Each node represents a crop prebreeding or breeding group and links represent potential dispersal of resistance genes between groups. In the cassava network, there are few private breeders, and a limited number of breeders overall. In the potato network, both public and private potato breeders exist in high-income countries but, in low- and middle-low income countries, there are primarily public breeding programs and few, if any, private potato breeders. This is because formal seed systems either do not exist or provide seed to a very small number of farmers (Thomas-Sharma et al. 2016); thus, there is no mechanism for private breeders to make profits. In the rice network, resistance genes for bacterial blight and blast have been combined in high-yielding backgrounds by the public sector and made available to anyone who wants them. Private breeding companies have limited investment in rice because there has not been an attractive business model for seed sales. However, over the last 10 to 15 years, companies have dramatically increased their investments in hybrid rice seed businesses. With an increase in their interests in hybrid rice, with its proven business model, companies (multinationals and smaller companies) are taking these resources and incorporating the resistance into their hybrids. If hybrids come to dominate the market, then resistance genes will move very quickly. However, uptake of hybrids currently is slow because of limitations on grain quality and seed costs. Uptake of resistance genes in inbred rice varieties is very slow, because the uptake of these varieties from the public sector can be extremely slow (e.g., it can take 25 years for a well-appreciated variety to spread to its maximum geographic distribution). Until recently, global wheat breeding was dominated by publicly funded programs. Legal protections such as Plant Variety Protection (PVP) and plant patents have encouraged investments by numerous large agricultural companies. Newer technologies such as hybrid wheat, genomic selection, and transgenics offer companies many opportunities to increase market share and profit margins. One result of the pursuit of competitive advantages is a decrease in free exchange of information and genetic resources by both public and private wheat breeding programs. Discovery, prebreeding, and dissemination of disease resistance gene resources in wheat remain primarily the domain of publicly funded institutions such as government research agencies, universities, and international agricultural research centers. 
continents than between continents, often due to phytosanitary and biodiversity laws, which serve as regulatory checkpoints. In some cases in the past, germplasm has moved across national borders between recipient countries to a greater extent (for example, when regional potato networks existed in the 1990s) but difficulty in meeting phytosanitary requirements has minimized this movement. In high-income countries, intellectual property laws may serve as major limiters to gene exchange while institutional limitations can reduce gene exchange in low-income countries. These limitations may be circumvented at the farm level to some extent by local farmerto-farmer exchange of seed, allowing some additional access to germplasm, but such exchange would be strongly dependent on distance between agents and other social factors.

Epidemic impacts on network structure. The crop breeding network structures also reflect important restrictions on germplasm movement that have been implemented to limit the risk of movement of pests and pathogens among countries and regions (Fig. 3). In the case of cassava, key yield-limiting diseases include cassava mosaic

TABLE 1. Network descriptors applied to global crop breeding networks for cassava, potato, rice, and wheat

\begin{tabular}{|c|c|c|}
\hline Descriptor & Interpretation & Results for crop breeding networks \\
\hline Node degree (distribution) & $\begin{array}{l}\text { Node degree is the number of links associated with a node. } \\
\text { In-degree and out-degree can be considered separately. }\end{array}$ & $\begin{array}{l}\text { CGIAR centers have high out-degree, and often high in- } \\
\text { degree, as well. Private groups generally have higher in- } \\
\text { degree than out-degree. Some nodes only have links from } \\
\text { CGIAR centers. }\end{array}$ \\
\hline Node closeness & $\begin{array}{l}\text { Closeness reflects how many links must be traveled through } \\
\text { to reach other nodes. Directed closeness would indicate } \\
\text { how many steps a node is from other gene sources. }\end{array}$ & $\begin{array}{l}\text { Most nodes are close to CGIAR centers. Most nodes are } \\
\text { farther from most nodes in other continents, where } \\
\text { pathways may not exist. }\end{array}$ \\
\hline Node betweenness & $\begin{array}{l}\text { Betweenness indicates a node's role as a bridge between } \\
\text { network regions. }\end{array}$ & $\begin{array}{l}\text { CGIAR centers clearly have high betweenness, as do some } \\
\text { regional nodes. Private groups generally have low } \\
\text { betweenness. }\end{array}$ \\
\hline Node neighbor traits & $\begin{array}{l}\text { Traits of neighboring nodes are another important factor, } \\
\text { where proximity to nodes with high degree or } \\
\text { betweenness can be beneficial for access to resistance } \\
\text { genes. }\end{array}$ & $\begin{array}{l}\text { Nodes can access resources through CGIAR centers, but } \\
\text { links to regional hubs can also be important for ensuring } \\
\text { access to resistance genes. }\end{array}$ \\
\hline Diameter and average path length & $\begin{array}{l}\text { The diameter of a network is the length of the longest path } \\
\text { between any two nodes in the network. All else being } \\
\text { equal, longer paths indicate lower likelihood that genes } \\
\text { will move through the complete path. }\end{array}$ & $\begin{array}{l}\text { Existing path lengths across regions are relatively short but } \\
\text { there are no paths between some pairs of breeding groups. } \\
\text { Within a region, longer paths may exist for wheat and rice } \\
\text { in Asia. }\end{array}$ \\
\hline Cliques and $k$-cores & $\begin{array}{l}\text { Cliques are groups of nodes, all of which are linked to each } \\
\text { other. } K \text {-cores are groups where nodes have at least } k \text { links } \\
\text { within the group. These groups are more likely to deploy } \\
\text { the same resistance genes. }\end{array}$ & $\begin{array}{l}\text { Clique and } k \text {-core structure is strongly determined } \\
\text { geographically. This likely results in increased risk of } \\
\text { evolution to virulence within a region but may protect } \\
\text { other regions with different gene deployment. }\end{array}$ \\
\hline Clustering & $\begin{array}{l}\text { Similarly, clustering is a measure of group structure, often } \\
\text { based on the probability that two nodes linked to a third } \\
\text { node are also linked to each other. }\end{array}$ & $\begin{array}{l}\text { Geographic structure drives clustering similarly across all } \\
\text { four crops, where rice and wheat have particularly large } \\
\text { clusters in China. }\end{array}$ \\
\hline
\end{tabular}
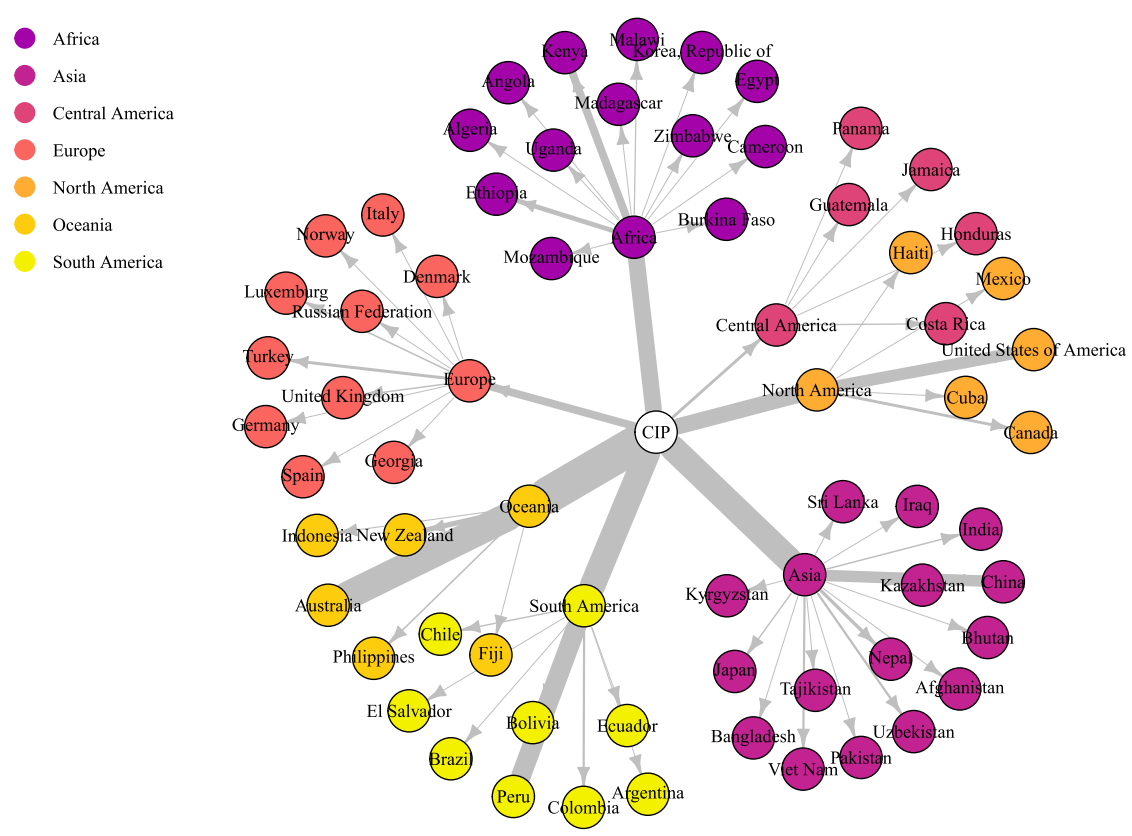

Fig. 4. Network graph representing genetic material distributed by the International Potato Center (CIP) from 2010 to 2014. Data were obtained from the CIP Biomart database and include all institutions and nations that requested and received accessions from CIP during this time. Transactions were aggregated by nation and world region. The white center node represents CIP, the originating institution. Transactions were grouped by seven world regions (Europe, Africa, Central America, North America, Asia, South America, Oceania, and Europe) and links between CIP and these regions were weighted by the total number of transactions to nations in the given region during that time, where line thickness is proportional to number of transactions. Note that these regional nodes (Africa, Europe, and so on) do not represent central institutions that distribute material that is received from CIP but are merely included to illustrate regional groupings. Links from regional nodes to nations illustrate transactions from CIP to individual nations, weighted by total number of transactions. Although germplasm was received by an institution within a nation, it is not known what the downstream use of this material was. For example, it could be used for breeding, selection, observation, or genetic analysis. All institutions (public and private) were pooled within countries. 
disease (CMD) and cassava brown streak disease (CBSD), vectored by a white fly (Bemisia tabaci) (Legg et al. 2014). These diseases are endemic to Africa, with some occurrence in India; however, there is a new report of CMD in Cambodia, representing spread to a node in a new region, where current germplasm is known to be highly susceptible (Wang et al. 2015). In this example, germplasm networks will need to adapt to deploy resistance to newly affected areas. In Africa, the biology of the viruses and the vector is more complex than in Southeast Asia, with multiple viruses and strains. The intentional deployment of CMD-resistant cassava from West Africa to East Africa may also have inadvertently contributed to increased occurrence of the second virus complex causing CBSD. Changes in vector populations were also a key driver for changing viral disease patterns in East Africa, including the role of superabundant B. tabaci populations (Legg et al. 2011). The development of host plant resistance to CMD in Africa is important but also a potential source of vulnerability. Recent genomic analyses appear to show that the genetic basis of resistance to CMD is more narrow than initially suspected. The major source of resistance appears to be durable; however, the idea of durability is also controversial in this system due to cases that may represent the breakdown of resistance. For pests of cassava, there are important examples of both genetic resistance and biological control methods. The use of these methods has been strongly affected by networks of researchers linked with donors who support research, in addition to farmer decision-making about technology adoption. In the absence of private breeding programs, donor decision-making about long-term and short-term strategies and about responses to system stresses will strongly influence the cassava system.

In potato, two major cases where resistance genes have been highly influential are the management of potato late blight (caused by Phytophthora infestans) and several potato viruses. Potato viruses can accumulate over successive cycles of vegetative reproduction and cause yield decline, a condition referred to as seed degeneration (ThomasSharma et al. 2016). To date, at least 20 resistance genes for resistance to P. infestans have been cloned (Rodewald and Trognitz 2013) and, after futile efforts to use these singly, they are now being stacked to try to attain more durable resistance (Haesaert et al. 2015). To monitor pathogen evolution to these genes, a novel host plant differential set has been developed (Zhu et al. 2015). Virus resistance genes have not been cloned but have been identified for Potato virus Y, Potato virus X (Kopp et al. 2015), and Potato leaf roll virus (Mihovilovich et al. 2014). These genes confer extreme or hypersensitive resistance, and are widely used in low-income countries where seed systems are underdeveloped.

The rice breeding network is also highly affected by $R$ gene deployment. $\mathrm{RB}$ and $\mathrm{BB}$ continue to pose constant threats to rice yields. At least $25 \mathrm{RB}$ and $39 \mathrm{BB}$ resistance genes have been molecularly characterized, and most of them control race-specific resistance activated by specific pathogen avirulence (Avr) genes (Leung et al. 2015). The availability of molecular markers tightly linked or specific to resistance genes has significantly advanced the utilization of $\mathrm{RB}$ and $\mathrm{BB}$ resistance genes for breeding resistant rice varieties via MAS (Ashkani et al. 2015; Rao et al. 2014). Regional pathogen surveillance has been implemented to determine pathogen race composition using $R$-gene-based differential lines and diagnosis based on pathogen $A v r$ genes. This type of surveillance is vital for efficient resistance gene flow within the breeding network as well as regional cultivar deployment (Dossa et al. 2015; Selisana et al. 2017). Three international CGIAR centers-IRRI, CIAT, and AfricaRicealong with National Agricultural Research and Extension Services partners, have collaborated to characterize pathogen population diversity for the strategic deployment of these resistance genes. Some broad-spectrum resistance genes are frequently identified as effective in specific rice-growing regions (e.g., the $\mathrm{Pi} 2$ and $\mathrm{Pi} 9$ genes for $\mathrm{RB}$ in Asia, Africa, and Latin America) which, in turn, may unwittingly narrow the diversity of the resistance gene pool for rice breeding programs. Due to the arms-race nature of $R-A v r$ interactions, utilization of a limited number of $R$ genes could drive the emergence of the same virulent pathogen races worldwide. To lower the risk of failure of race-specific $R$ genes, QTLs have been mapped and provide a very effective alternative form of host resistance. It has been shown that pyramiding four QTLs can provide a level of resistance similar to

TABLE 2. Principles for supporting system resilience, adapted from Biggs et al. (2012), and potential application to global crop breeding networks ${ }^{\mathrm{a}}$

Principles $^{\mathrm{b}} \quad$ Principles applied to global crop breeding networks

1. Diversity and redundancy

The benefits of deploying stacks of resistance genes that act independently, or strategic deployment of a range of resistance genes in mixtures, are well known. Mechanisms that result in different pools of resistance genes being deployed for different purposes may help to create useful forms of functional diversity for genes. A global crop breeding system with a critical mass of crop breeders who represent a range of incentive structures and crop breeding strategies may provide a form of insurance and make the system more likely to successfully adapt to the challenges of global change. For some systems such as maize, crop breeding is highly privatized. For other systems, such as most tropical fruit crops, the very small number of crop breeders represents a system vulnerability.

2. Management of connectivity At the same time that the spread of resistance genes provides benefits for global resistance deployment, the spread of pathogens with crop germplasm or crops postharvest (Hernandez Nopsa et al. 2015) is one obvious risk of connectivity among regions. Another potential risk of resistance gene dispersal is an increased probability of deployment in ways that decrease the useful life of genes. Information flows among crop breeders will generally enhance decision-making and system success.

3. Management of feedback

Immediate feedback for crop breeders includes the hectarage over which their new varieties are grown. Followon feedback in crop breeding networks includes disease and pest responses to resistance gene deployment and resulting profitability responses. Currently, potential regime shifts (Scheffer et al. 2012) for some crops may occur due to increased use of hybrids or herbicide-resistant varieties, with rapid feedback to privatize crop breeding systems. The resulting shift in incentives has the potential to push the system beyond a threshold, such that deployment and dispersal of resistance genes would slow as pesticide sales become more profitable. Understanding global crop breeding networks as systems may enhance the ability of planners and policy makers to strengthen the systems and prioritize resource investment. Conceptualizing crop breeding systems as part of broader systems providing ecosystem services may be useful, along with a longer-term perspective on gene stewardship that does not discount the future so strongly (Cheatham et al. 2009; Levin et al. 2012; Messier et al. 2014). Active participation of a wider range of stakeholders could help to insure that the deployment of resistance genes meets the needs of farmers and of society more broadly. Effective information flows from farmers to crop breeders could also improve system responses to new stressors.

Having multiple "governing authorities" at multiple scales may improve crop breeding networks through effective regulation in combination with market forces. Challenges include matching the scale of governance to the scale of potential problems, and making effective group decisions to handle trade-offs among the goals of different stakeholders (Biggs et al. 2012).

6. Promoting polycentric governance systems

a Some principles may apply to both the resistance genes themselves and the agents who disperse and deploy them.

b Adapted from Biggs et al. (2012).

c $\mathrm{CAS}=$ complex adaptive systems 
that provided by $R$ genes for controlling RB (Fukuoka et al. 2015). Two QTLs (pi21 and $\mathrm{Pb} 1$ ) have been included in the RB resistance breeding program at AfricaRice, promoting the diversity of the resistance gene pool for durable resistance in rice (Bimpong et al. 2014).

In the case of wheat breeding, rusts have been an ongoing focus, with dramatic new system stressors in recent years (Beddow et al. 2015; Helfer 2014; Hulbert and Pumphrey 2014). Stem rust may offer the best example of the complexities of global deployment of resistance gene resources in wheat. In the 20th century, stem rust was largely brought under control through programs to eradicate the alternate host, barberry, and through the use of genetic resistance. One of the most important $R$ genes was $S r 31$ (McIntosh et al. 1995), which was durable for many decades and was arguably the most widely exploited and most valuable $R$ gene in wheat. Unfortunately, this gene was typically deployed singly or with other $\mathrm{Sr}$ genes that were already defeated, and little thought was given to conscious stewardship of $S r 31$ or to implementing strategies to replace it when needed. In 1999, a new race of stem rust, Ug99, was discovered in Uganda attacking wheat lines with $\operatorname{Sr} 31$. The new race was found to be highly virulent on $\mathrm{Sr} 31$ as well as most known stem rust $R$ genes, leaving most global wheat varieties vulnerable (Singh et al. 2015). Led by Nobel Laureate Norman Borlaug, a new global rust initiative was founded with the goal of mobilizing new genetic resistance resources to fight Ug99. Known $R$ genes $\mathrm{Sr} 24$ and $\mathrm{Sr} 36$ were identified as being effective against Ug99, and work began on incorporating those genes into new cultivars. However, each of those genes was soon overcome by new variants of the Ug99 lineage in East Africa, most likely because they were already deployed individually in local wheat varieties. Shortterm disease control has generally been favored over long-term utility of valuable genetic resistance resources. The global wheat germplasm exchange network has been very useful and effective (Byerlee and Dubin 2009). Theoretically, combinations of disease resistance genes are much more durable than single genes. However, this is only true if deployment of the same resistance genes singly can be prevented. Preventing single deployment can be achieved through either legal means such as patents or through community cooperation in a gene stewardship plan. An alternative approach has been to identify, accumulate, and share partial or quantitative resistance genes, which individually have small effects but are thought to be less prone to defeat by pathogens (Singh et al. 2015).

Increased privatization of plant breeding. In the early 20 th century, public institutions such as universities were the primary institutions tasked with breeding modern crop varieties. Since the introduction of hybrid technologies in the 1920s, and particularly since the development of biotech traits in the 1970s, there has been an increased shift in crop breeding R\&D efforts from the public to the private sector. This shift has been catalyzed largely by international changes in intellectual property (IP) laws introducing stronger utility patent protections on genetic materials, along with decreased regulation around international germplasm movement, facilitating the growth of private enterprises in this sector (Frey 1996; Heisey et al. 2001; Luby et al. 2015; Morris et al. 2006). For many highvolume crops in industrialized markets, private companies have all but replaced the role of the public sector in finished variety release and distribution (Heisey et al. 2001; Luby et al. 2015). Furthermore, there has been a recent, rapid consolidation of the seed and trait industry within the private sector, resulting in larger, consolidated germplasm and IP pools (Galushko et al. 2012; Howard 2015). The involvement of the private sector in plant breeding is highly cropand region-specific, with a focus on high production crops with high acreage (corn, soybean, and cotton, for example). The entrance of private companies provides a large influx of R\&D and market competition into these cropping systems, with the potential to accelerate genetic gain (Pray and Fuglie 2015).

The genetic material of any breeder, institution, or nation is a highly valuable asset. When sharing genetic material within the public sector or with the private sector, public breeders must consider IP laws, material transfer agreements, and licensing costs which may, in some cases, prove prohibitive and lead to "crises" for material exchange. Open-source breeding movements have attempted to address these limitations (Laursen 2017), but it is unclear whether these efforts can have a major effect on crop breeding networks. A survey conducted by Galushko et al. (2012) observed a decrease in the likelihood of exchanging material in a crop system that is highly privatized, such as canola, when compared with another which is highly public, such as wheat. Private breeding research programs are influenced by the needs of the market for plant disease resistance. In general, research priorities around disease and pest resistance will mirror current grower demands in high-profit regions. The acquisition of novel disease resistance traits from the public domain is, in many cases, a good return on investment for private crop breeders. Resistance genes in the private sector for which there is high demand, such as Bt resistance to insect pests, can reshape crop breeding networks. Of course, resistance genes and traits may flow not only to and from the public and private sector but also among private sector companies.

Evaluating and interpreting the structure of networks. The topology and other features of these crop breeding networks suggest that they have certain strengths and weaknesses. For example, one trait of public breeding groups (Fig. 3) is the tendency toward modularity, or clustering, where modules often occur within continents because the number of links within continents is higher than the number of links among continents. This inherent community structure is likely a result of complex phytosanitary and regulatory restrictions, as well as the difficulty of adapting varieties to new regions with differing environments, market classes, or maturity groups. Modularity may make the networks more resilient to problems such as the spread of pests through germplasm (Ash and Newth 2007), where the problem might at least be stopped before the pest leaves a module. These networks feature key public institutions in the CGIAR system as hubs for dispersal of resistance genes (Galluzzi et al. 2016; Renkow and Byerlee 2010), along with some large national programs (Smale and Day-Rubenstein 2002). Alternatives to conventional crop breeding networks, such as organic crop breeding networks and networks for the exchange of traditional varieties (Pautasso et al. 2013), may also increase the overall resilience of $R$ gene deployment if they deploy different types of resistance genes. Modularity can also be a weakness because individual decision makers in various nodes can prevent larger strategic initiatives from being implemented and also limit exchange of varieties, priorities, and knowledge, especially in cases where nontraditional actors and networks are particularly important.

A primary question when evaluating crop breeding networks is whether their structure results in resistance genes being developed and deployed for the optimal benefit to food security. The topology of crop breeding networks helps to determine whether this will be the case. For example, if there is a shift in directionality, such that the major international crop breeding groups change from being public groups with high out-degree (a high number of links leading outward from a node) to being private groups with high in-degree (a high number of links leading into a node), this may provide different challenges for optimal deployment of resistance genes (Fig. 5). For example, it may not be profitable to develop resistant varieties adapted to the needs of resource-poor farmers. However, funding of private groups is not limited by availability of public funds and donor money and, if expected profitability can be demonstrated, more new varieties may be produced. Alston et al. (2009) indicate that, for agricultural research in general, much development benefiting resource-poor farmers has been a positive externality for research targeting wealthier farmers, who constitute larger markets in wealthy countries. Analyses similar to epidemic network analysis can also provide perspective on the likely success of crop breeding networks. One key aspect is the length of the lag between observed emergence of new pathogen types in the field and network response to provide an elite cultivar with appropriate resistance. Epidemiology and risk assessment can contribute to shortening this lag time through regional and global monitoring, and predictions of the breakdown of resistance genes and of invasions of new pathogens, to provide more 
efficient feedback about epidemics to inform the priorities of crop breeders. Monitoring of virulence in the field has already proven useful for the efficient deployment of resistance genes in the rice breeding network. Understanding the structure of epidemic networks and how they change over time can guide efficient monitoring (Sanatkar et al. 2015; Sutrave et al. 2012).

The representation of the crop breeding networks depicted here allows conclusions about the general structure of the networks (Fig. 3 ) and subsequent implications for the deployment of resistance. More detailed analysis of specific crop networks will allow additional conclusions about whether the network structure is advantageous for particular regions and purposes. For example, from the standpoint of a particular region, how well does the network function to provide needed resistance genes, in enough variety to provide more durable resistance? This can be evaluated, in part, by considering network features such as the node degree distribution (the frequency with which each potential node degree occurs) (Table 1). If a network is "scale-free" (Shaw and Pautasso 2014), there are nodes of high degree that help to maintain distribution through the network. CGIAR breeding groups have high out-degree but may have their capacity constrained by monetary resources, whereas private breeding groups may instead have high in-degree and low out-degree but access to more monetary resources. If a network is a "small world" network (Shaw and Pautasso 2014), there are links that cross different components of the network, keeping the number of steps between any two nodes low. Cut-point analysis can identify nodes which, if removed, would substantially reduce the network coherence; in the current network, removal of CGIAR breeding groups would have a large effect to reduce coherence.

A key question is how readily new viable public and private breeding groups can arise to replace ones that might be lost from the system, and how readily new links between breeding groups can form to compensate for lost groups. The vulnerability of the ICARDA seed collections in Aleppo, Syria, is a striking example of the need for system redundancy (Bhattacharya 2016). In 2015, the ICARDA seed bank withdrew from its reserves in the Svalbard Global Seed Vault when ICARDA relocated to Lebanon and Morocco (Gruber 2017). The Seed Vault was established in 2008 to provide gene banks with a place to store duplicates of their collections, only to be drawn upon in the case of substantial loss or catastrophe (Westengen et al. 2013), but it may also be vulnerable, itself, to factors such as climate change.

Other traits of more detailed networks can be considered such as controllability, the ability of a set of driver nodes to push the network toward a desired state (Liu et al. 2011). In the coarse perspective on networks presented here, it is clear that CGIAR breeding groups and large international private breeding groups are key to controlling the state of the global crop breeding network. They are also likely to complement each other in some areas and compete in others, and future research needs to clarify where and how in more detail. At a regional level, with more detailed information, there are likely secondary levels of key driver breeding groups, whose roles in network resilience would be useful topics for more detailed analysis.

The information networks associated with crop breeding networks, and innovation networks more broadly, are also a key system component (Garrett 2012, 2017; Poland 2015; Spielman et al. 2009). As gene editing technologies advance, the movement of physical materials may at some point no longer be necessary because information about DNA sequences alone may be enough for crop breeders to incorporate new forms of resistance. This development increases the importance of capacity in the different nodes and, without active policies, this may increase the competitiveness of private breeders and increase the challenges for breeders in general, and especially for implementing joint strategies in low-income countries.

The goal of system resilience has led to the development of a number of principles for improved systems (Table 2), although many concepts about resilience remain to be tested because the science of resilience is still in its early stages (Biggs et al. 2012; Donohue et al. 2016; Ostrom 2009; Scheffer et al. 2012). The scale of global crop breeding networks makes experimentation difficult. However, observational analyses of successes and failures in the history of $R$ gene deployment as a function of crop breeding network structure could provide useful insights. Strengthening crop breeding programs in regions that are underserved by the current networks may improve the system-level outcomes of global crop breeding networks (Ribaut et al. 2010; Rivers et al. 2015) but the market incentives in better-served regions may well increase the disparity in service levels. An important form of system-level research will also be to evaluate potential system interventions to aid in prioritization when resources to invest in system improvement are

Directionality and the likelihood that resistance genes are available to farmers where needed
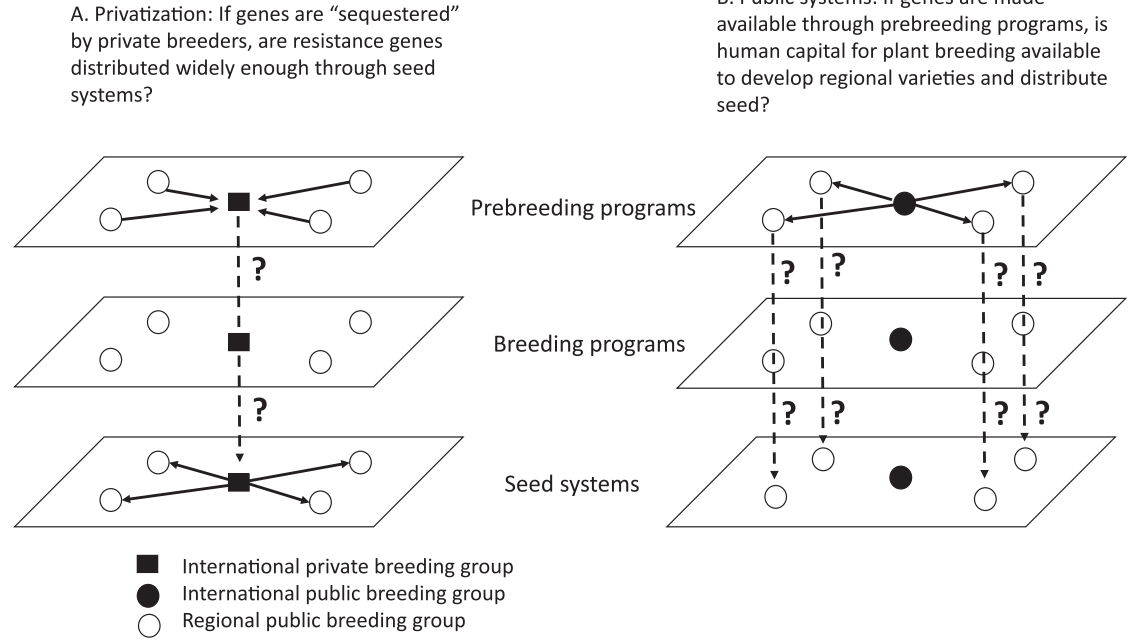

B. Public systems: If genes are made available through prebreeding programs, is human capital for plant breeding available to develop regional varieties and distribute

Fig. 5. Directionality of links is a key feature of the multilayer networks that make resistance genes available for farmers to use. These schematic diagrams indicate

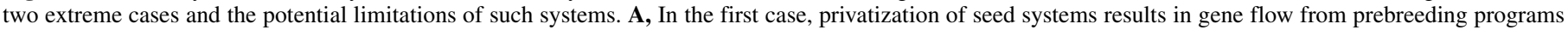

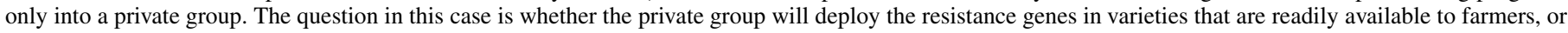

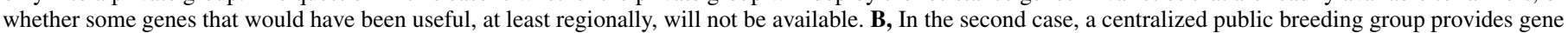

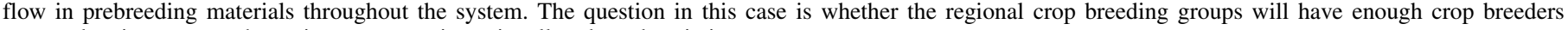
prepared to incorporate the resistance genes in regionally adapted varieties. 
limited, and provide incentives to provide public goods. Resistance gene deployment offers additional challenges for resource investment strategies compared with genes such as those for drought tolerance, because deployment strategies used by some actors can reduce the utility of resistance genes for other actors in the system (Fig. 6).

In conclusion, we have illustrated the general structure of the crop breeding networks that determine the global pattern of resistance gene deployment for four major food crops. Finer-resolution analyses of crop breeding networks will help to guide policies for better global and regional network structures, particularly in the context of agricultural development. A key research question is how policies can optimize the balance between public and private breeding groups to provide the societal benefits of strategic resistance gene deployment in optimal landscape patterns for disease and pest management. There are exciting opportunities to draw on the growing field of network analysis as a source of

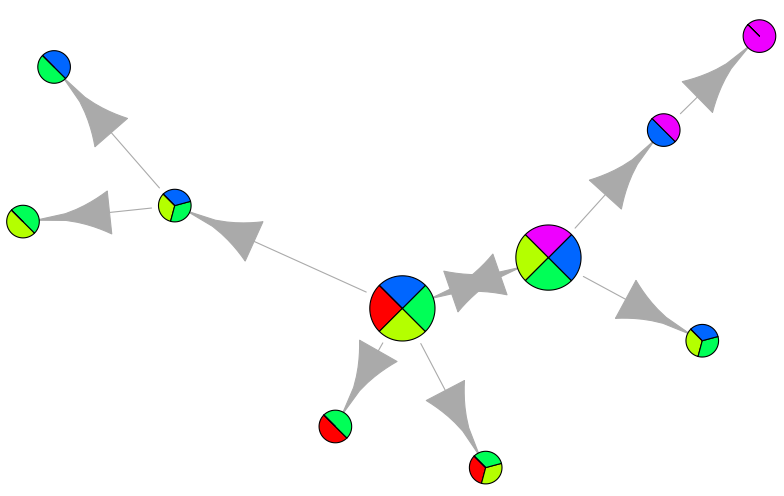

A System-level hypothesis

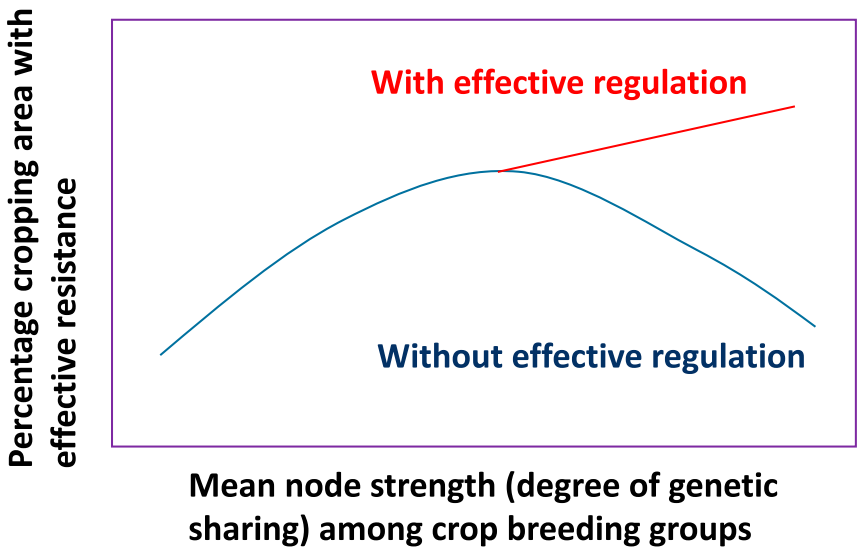

\section{B System-level hypothesis}

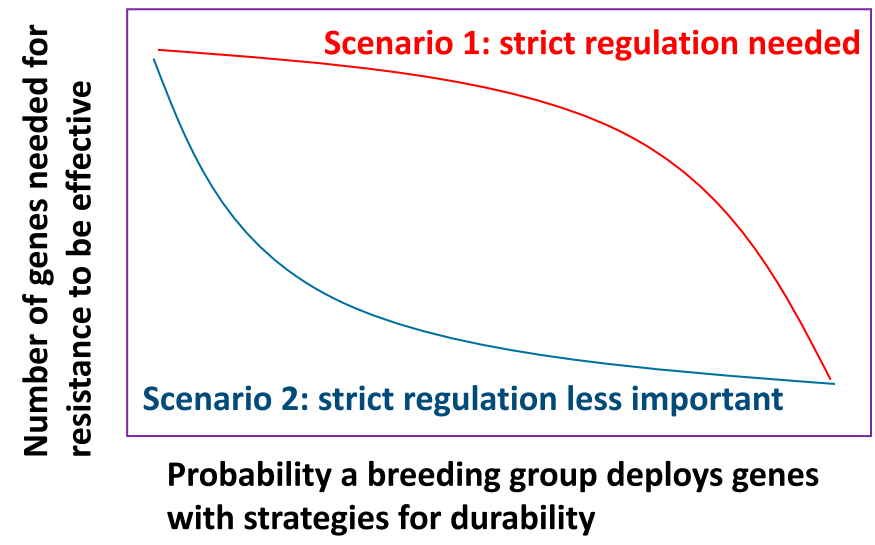

input for strategies. General research priorities to support policy making include the following.

1. How can better understanding of global crop breeding networks as part of a CAS (Fig. 1) contribute to improved policy making? Conceptualizing the larger system as a CAS is intellectually stimulating, but how can this conceptualization help us draw conclusions about the system and how to improve it? For example, how can system-level understanding contribute to prioritizing investments for pest and disease risk, enhancing the useful life of resistance genes, and adaptation to climate change?

2. Understanding network structures provides some immediate insights into the likely functioning of crop breeding networks (Fig. 2). How can these insights best be enhanced through links with network theory, such as ideas about network sustainability, resilience, controllability, and reliability?

3. Likewise, estimates of the current structure of crop breeding networks for cassava, potato, rice, and wheat offer some immediate insights about the roles of key nodes (Fig. 3). How can understanding of these structures best be expanded into understanding of the mechanisms that support the formation and dissolution of links between crop breeding groups? How will these mechanisms allow crop breeding networks to adapt to new system stressors (Fig. 1)? How can investments in capacity building best be targeted as breeding programs adapt to climate stressors and increased food production needs?

4. What is the nature of fine-scale regional crop breeding network interactions? Are the ERGM-like approaches used here adequate to describe them? How can the types of public breeding group information that are more readily available (Fig. 4) best be integrated with private breeding group information, and how can private group information be approximated when it is generally difficult to obtain? How can regional crop breeding groups be better integrated into global systems for both access to resistance genes and access to relevant information?

Fig. 6. Hypothetical crop breeding network, where different shades represent different resistance genes. As resistance genes move through the network, subsetting may result in regional "specialization", such that regions served by one crop breeding group may have access to different sets of resistance genes than regions served by other crop breeding groups. This may be disadvantageous to regions that would benefit from access to a wider range of resistance genes, but it may be advantageous to the system as a whole if adequate disease management occurs and there is less system-wide selection for virulence to particular genes. (The figure may suggest commonalities with haplotype networks. The concepts have some similarities although, in this figure, a node represents the resistance gene deployment in varieties in a region served by a particular crop breeding group.) Two hypotheses about resistance genes in cropping breeding networks follow. Hypothesis A, Sharing of genetic resistance resources has practical risks and rewards, as well as the ethical implications of providing or withholding support for enhanced food security. As the level of sharing of genetic material among crop breeders increases, the percentage of cropping area in which effective resistance is deployed increases, up to a point. The increase in area with effective resistance is due to increased availability of resistance genes for breeding programs. The decrease in area with effective resistance at higher levels of sharing is due to the potential for breakdown in effectiveness of genes as more breeders use the genes and, thus, the probability of deployment without a strategy to protect gene utility increases. Policies to support resistance gene stewardship can make the benefit of gene sharing continue through higher levels of sharing. Hypothesis B, For different crop breeding systems, there may be different scenarios related to the importance of effective policies. In general, as the probability increases that any given breeding group uses effective strategies for gene deployment, the number of genes necessary for the system to be successful decreases. For some systems (scenario 1), the decrease in the number of genes necessary may decline slowly, so that strict policies are needed even when most groups use effective strategies. For other systems, (scenario 2), the decrease in the number of genes occurs with a small increase in the probability that breeding groups use effective strategies and, thus, policies are less important. Use of quantitative trait loci rather than major genes for resistance may also make scenario 2 more likely than scenario 1 . 
5. As breeding groups privatize, this generally weakens the network structure. To what extent do private groups compensate for this, from the standpoint of the larger system, by proportionately strengthening seed distribution networks (Fig. 5) so that resistance genes are available where needed?

6. How does movement of breeding materials through networks modify the probability that resistance genes will be deployed alone or in combination (Fig. 6)? How do trade-offs play out when resistance to multiple pathogens or pests is desirable? When resistance genes are available, what factors may limit their use at the same time that pesticides are widely used-and what policies can change this balance, even if the costs and benefits to stakeholders are not evenly distributed? How do the resulting landscapes of resistance gene deployment influence epidemics and food security?

\section{ACKNOWLEDGMENTS}

We thank S. De Haan for information about cassava breeding networks; M. Bonierbale for information about potato breeding networks; R. S. Zeigler, R. K. Singh, and F. Xie for information about rice breeding networks; and G. Bai and S. Sehgal for information about wheat breeding networks. Phytopathology reviewers provided very helpful feedback for improving this article. This research was undertaken as part of, and funded by, the CGIAR Research Program on Roots, Tubers and Bananas and the CGIAR Research Program on Climate Change and Food Security, supported by CGIAR Fund Donors (http://www.cgiar.org/about-us/our-funders/). We acknowledge support for the Nextgen Cassava project by the Bill \& Melinda Gates Foundation and UKaid (Grant 1048542; http://www.gatesfoundation.org). This work was supported, in part, by other grants from the Global Rice Science Partnership (GRiSP), the SCPRID program of BBSRC (http://www.bbsrc.ac.uk/research/ grants/grants/AwardDetails.aspx? FundingReference=BB/J012157/1) and the Bill \& Melinda Gates Foundation. We also appreciate support by United States Department of Agriculture (USDA) Animal and Plant Health Inspection Service grant 11-8453-1483-CA, U.S. National Science Foundation (NSF) grant EF-0525712 as part of the joint NSF National Institute of Health Ecology of Infectious Disease program, and U.S. NSF grant DEB-0516046. Mention of trade names or commercial products in this publication is solely for the purpose of providing specific information and does not imply recommendation or endorsement by the USDA. USDA is an equal opportunity provider and employer.

\section{LITERATURE CITED}

Alston, J. M., Beddow, J. M., and Pardey, P. G. 2009. Agricultural research, productivity, and food prices in the long run. Science 325:1209-1210.

Anderson, J. R., Herdt, R. W., and Scobie, G. M. 1988. Science and food: The CGIAR and its partners. World Bank, Washington, DC.

Ash, J., and Newth, D. 2007. Optimizing complex networks for resilience against cascading failure. Phys. A (Amsterdam, Neth.) 380:673-683.

Ashkani, S., Rafii, M. Y., Shabanimofrad, M., Miah, G., Sahebi, M., Azizi, P., Tanweer, F. A., Akhtar, M. S., and Nasehi, A. 2015. Molecular breeding strategy and challenges towards improvement of blast disease resistance in rice crop. Front. Plant Sci. 6:886.

Bebber, D. P., Ramotowski, M. A. T., and Gurr, S. J. 2013. Crop pests and pathogens move polewards in a warming world. Nat. Clim. Chang. 3:985-988.

Beddow, J. M., Pardey, P. G., Chai, Y., Hurley, T. M., Kriticos, D. J., Braun, H.-J., Park, R. F., Cuddy, W. S., and Yonow, T. 2015. Research investment implications of shifts in the global geography of wheat stripe rust. Nat. Plants 1: Article 15132. doi:10.1038/nplants.2015.132

Bhattacharya, S. 2016. Syrian seed bank gets new home away from war. Nature 538:16-17.

Biggs, R., Schlüter, M., Biggs, D., Bohensky, E. L., BurnSilver, S., Cundill, G., Dakos, V., Daw, T. M., Evans, L. S., Kotschy, K., Leitch, A. M., Meek, C., Quinlan, A., Raudsepp-Hearne, C., Robards, M. D., Schoon, M. L., Schultz, L., and West, P. C. 2012. Toward principles for enhancing the resilience of ecosystem services. Annu. Rev. Environ. Resour. 37:421-448.

Bimpong, I. K., Manneh, B., Sock, M., Ndoye, I., Ismail, A. M., Gregorio, G., Sie, M., Diaw, F., Nakano, M., and Wopereis, M. 2014. Germplasm development for blast disease, cold tolerance and salt affected environments: Progress made in breeding and genetic analysis at Africa RICE Center. Pages 277-278 in: ASA, CSSA, \& SSSA Int. Annu. Meet. Long Beach, CA.

Boyd, L. A., Ridout, C., O'Sullivan, D. M., Leach, J. E., and Leung, H. 2013. Plant-pathogen interactions: Disease resistance in modern agriculture. Trends Genet. 29:233-240.
Buddenhagen, C. E., Hernandez Nopsa, J. F., Andersen, K. F., Andrade-Piedra, J., Forbes, G. A., Kromann, P., Thomas-Sharma, S., Useche, P., and Garrett, K. A. 2017. Epidemic network analysis for mitigation of invasive pathogens in seed systems: Potato in Ecuador. Phytopathology 107:1209-1218.

Byerlee, D., and Dubin, H. J. 2009. Crop improvement in the CGIAR as a global success story of open access and international collaboration. Int. J. Commons 4:452-480.

Chapman, S. C., Chakraborty, S., Dreccer, M. F., and Howden, S. M. 2012. Plant adaptation to climate change-Opportunities and priorities in breeding. Crop Pasture Sci. 63:251-268.

Cheatham, M. R., Rouse, M. N., Esker, P. D., Ignacio, S., Pradel, W., Raymundo, R., Sparks, A. H., Forbes, G. A., Gordon, T. R., and Garrett, K. A. 2009. Beyond yield: Plant disease in the context of ecosystem services. Phytopathology 99:1228-1236.

Csárdi, G., and Nepusz, T. 2006. The igraph software package for complex network research. Online publication. InterJournal Complex Syst. Article 1695. http://www.interjournal.org/manuscript_abstract.php?361100992

Deans, A. R., Lewis, S. E., Huala, E., Anzaldo, S. S., Ashburner, M., Balhoff, J. P., Blackburn, D. C., Blake, J. A., Burleigh, J. G., and Chanet, B. 2015. Finding our way through phenotypes. PLoS Biol. 13:e1002033.

Dempewolf, H., Eastwood, R. J., Guarino, L., Khoury, C. K., Müller, J. V., and Toll, J. 2014. Adapting agriculture to climate change: A global initiative to collect, conserve, and use crop wild relatives. Agroecol. Sustain. Food Syst. 38:369-377.

Donohue, I., Hillebrand, H., Montoya, J. M., Petchey, O. L., Pimm, S. L., Fowler, M. S., Healy, K., Jackson, A. L., Lurgi, M., McClean, D., O’Connor, N. E., O'Gorman, E. J., and Yang, Q. 2016. Navigating the complexity of ecological stability. Ecol. Lett. 19:1172-1185.

Dossa, G. S., Sparks, A., Vera Cruz, C., and Oliva, R. 2015. Decision tools for bacterial blight resistance gene deployment in rice-based agricultural ecosystems. Front. Plant Sci. 6:305.

Esquinas-Alcázar, J. 2005. Protecting crop genetic diversity for food security: Political, ethical and technical challenges. Nat. Rev. Genet. 6:946-953.

Evenson, R. E., and Gollin, D. 2003. Crop Variety Improvement and its Effect on Productivity: The Impact of International Agricultural Research. CABI Publishing, Wallingford, UK.

Fowler, C., and Hodgkin, T. 2004. Plant genetic resources for food and agriculture: Assessing global availability. Annu. Rev. Environ. Resour. 29:143-179.

Frey, K. J. 1996. National plant breeding study-1: Human and financial resources devoted to plant breeding research and development in the United States in 1994. Iowa Agric. Home Econ. Exp. Stn. Rep. No. 98.

Fukuoka, S., Saka, N., Mizukami, Y., Koga, H., Yamanouchi, U., Yoshioka, Y., Hayashi, N., Ebana, K., Mizobuchi, R., and Yano, M. 2015. Gene pyramiding enhances durable blast disease resistance in rice. Sci. Rep. 5: Article 7773. doi:10.1038/srep07773

Galluzzi, G., Halewood, M., Noriega, I. L., and Vernooy, R. 2016. Twenty-five years of international exchanges of plant genetic resources facilitated by the CGIAR genebanks: A case study on global interdependence. Biodivers. Conserv. 25:1421-1446.

Galushko, V., Gray, R., and Oikonomou, E. 2012. Operating in an intellectual property world: Knowledge sharing among plant breeders in Canada. Can. J. Agric. Econ. 60:295-316.

Garrett, K. A. 2012. Information networks for plant disease: Commonalities in human management networks and within-plant signaling networks. Eur. J. Plant Pathol. 133:75-88.

Garrett, K. A., Dobson, A. D. M., Kroschel, J., Natarajan, B., Orlandini, S., Tonnang, H. E. Z., and Valdivia, C. 2013. The effects of climate variability and the color of weather time series on agricultural diseases and pests, and decision-making for their management. Agric. For. Meteorol. 170:216-227.

Gruber, K. 2017. Agrobiodiversity: The living library. Nature 544:S8-S10.

Haesaert, G., Vossen, J. H., Custers, R., De Loose, M., Haverkort, A., Heremans, B., Hutten, R., Kessel, G., Landschoot, S., and Van Droogenbroeck, B. 2015. Transformation of the potato variety Desiree with single or multiple resistance genes increases resistance to late blight under field conditions. Crop Prot. 77:163-175.

Heffner, E. L., Sorrells, M. E., and Jannink, J.-L. 2009. Genomic selection for crop improvement. Crop Sci. 49:1-12.

Heisey, P. W., Srinivasan, C. S., and Thirtle, C. 2001. Public Sector Plant Breeding in a Privatizing World. U.S. Dep. Agric. Agric. Inf. Bull. No. 772. Helfer, S. 2014. Rust fungi and global change. New Phytol. 201:770-780.

Hernandez Nopsa, J. F., Daglish, G. J., Hagstrum, D. W., Leslie, J. F., Phillips, T. W., Scoglio, C., Thomas-Sharma, S., Walter, G. H., and Garrett, K. A. 2015. Ecological networks in stored grain: Key postharvest nodes for emerging pests, pathogens, and mycotoxins. BioScience 65:985-1002.

Holland, J. H. 1995. Hidden Order: How Adaptation Builds Complexity. AddisonWesley, New York.

Howard, P. H. 2015. Intellectual property and consolidation in the seed industry. Crop Sci. 55:2489-2495.

Hulbert, S., and Pumphrey, M. 2014. A time for more booms and fewer busts? Unraveling cereal-rust interactions. Mol. Plant-Microbe Interact. 27:207-214. 
Jarvis, A., Lane, A., and Hijmans, R. J. 2008. The effect of climate change on crop wild relatives. Agric. Ecosyst. Environ. 126:13-23.

Jeger, M. J., Pautasso, M., Holdenrieder, O., and Shaw, M. W. 2007. Modelling disease spread and control in networks: Implications for plant sciences. New Phytol. 174:279-297.

Kopp, A., Kondrák, M., and Bánfalvi, Z. 2015. Molecular mechanisms of resistance to Potato virus $X$ and $Y$ in potato. Acta Phytopathol. Entomol. Hung. 50:151-160.

Laursen, L. 2017. German breeders develop 'open-source' plant seeds. Online publication. Science doi:10.1126/science.aan6961

Legg, J., Somado, E. A., Barker, I., Beach, L., Ceballos, H., Cuellar, W., Elkhoury, W., Gerling, D., Helsen, J., and Hershey, C. 2014. A global alliance declaring war on cassava viruses in Africa. Food Secur. 6:231-248.

Legg, J. P., Jeremiah, S. C., Obiero, H. M., Maruthi, M. N., Ndyetabula, I., Okao-Okuja, G., Bouwmeester, H., Bigirimana, S., Tata-Hangy, W., Gashaka, G., Mkamilo, G., Alicai, T., and Kumar, P. L. 2011. Comparing the regional epidemiology of the cassava mosaic and cassava brown streak virus pandemics in Africa. Virus Res. 159:161-170.

Leung, H., Raghavan, C., Zhou, B., Oliva, R., Choi, I. R., Lacorte, V., Jubay, M. L., Cruz, C. V., Gregorio, G., Singh, R. K., Ulat, V. J., Borja, F. N., Mauleon, R., Alexandrov, N. N., McNally, K. L., and Hamilton, R. S. 2015. Allele mining and enhanced genetic recombination for rice breeding. Rice 8:34.

Levin, K., Cashore, B., Bernstein, S., and Auld, G. 2012. Overcoming the tragedy of super wicked problems: Constraining our future selves to ameliorate global climate change. Policy Sci. 45:123-152.

Levin, S. A. 1998. Ecosystems and the biosphere as complex adaptive systems. Ecosystems 1:431-436.

Liu, Y. Y., Slotine, J. J., and Barabasi, A. L. 2011. Controllability of complex networks. Nature 473:167-173.

Luby, C. H., Kloppenburg, J., Michaels, T. E., and Goldman, I. L. 2015. Enhancing freedom to operate for plant breeders and farmers through open source plant breeding. Crop Sci. 55:2481-2488.

Marden, E., and Godfrey, R. N. 2012. Intellectual property and sharing regimes in agricultural genomics: Finding the right balance for innovation. Drake J. Agric. Law 17:369-393.

Margosian, M. L., Garrett, K. A., Hutchinson, J. M. S., and With, K. A. 2009. Connectivity of the American agricultural landscape: Assessing the national risk of crop pest and disease spread. BioScience 59:141-151.

McDonald, B. A., and Linde, C. 2002. Pathogen population genetics, evolutionary potential, and durable resistance. Annu. Rev. Phytopathol. 40:349-379.

McIntosh, R. A., Wellings, C. R., and Park, R. F. 1995. Wheat Rusts: An Atlas of Resistance Genes. CSIRO Publishing, East Melbourne, Australia.

McRoberts, N., Hall, C., Madden, L. V., and Hughes, G. 2011. Perceptions of disease risk: From social construction of subjective judgments to rational decision making. Phytopathology 101:654-665.

Meadows, D. H., and Wright, D. 2008. Thinking in Systems: A Primer. Chelsea Green Publishing, White River Junction, VT.

Messier, C., Puettmann, K. J., and Coates, K. D., eds. 2014. Managing Forests as Complex Adaptive Systems: Building Resilience to the Challenge of Global Change. Routledge, London.

Mihovilovich, E., Aponte, M., Lindqvist-Kreuze, H., and Bonierbale, M. 2014. An RGA-derived SCAR marker linked to PLRV resistance from Solanum tuberosum ssp. andigena. Plant Mol. Biol. Rep. 32:117-128.

Miller, J. H., and Page, S. E. 2007. Complex Adaptive Systems: An Introduction to Computational Models of Social Life. Princeton University Press, Princeton, NJ.

Mills, P., Dehnen-Schmutz, K., Ilbery, B., Jeger, M., Jones, G., Little, R., MacLeod, A., Parker, S., Pautasso, M., Pietravalle, S., and Maye, D. 2011. Integrating natural and social science perspectives on plant disease risk, management and policy formulation. Philos. Trans. R. Soc. B Biol. Sci. 366:2035-2044.

Morris, M., Edmeades, G., and Pehu, E. 2006. The global need for plant breeding capacity: What roles for the public and private sectors? HortScience 41:30-41.

Moslonka-Lefebvre, M., Finley, A., Dorigatti, I., Dehnen-Schmutz, K., Harwood, T., Jeger, M. J., Xu, X. M., Holdenrieder, O., and Pautasso, M. 2011. Networks in plant epidemiology: From genes to landscapes, countries, and continents. Phytopathology 101:392-403.

Mundt, C. C. 2002. Use of multiline cultivars and cultivar mixtures for disease management. Annu. Rev. Phytopathol. 40:381-410.

Ostrom, E. 2009. A general framework for analyzing sustainability of socialecological systems. Science 325:419-422.

Pautasso, M., Aistara, G., Barnaud, A., Caillon, S., Clouvel, P., Coomes, O. T., Delêtre, M., Demeulenaere, E., De Santis, P., Döring, T., Eloy, L., Emperaire, L., Garine, E., Goldringer, I., Jarvis, D., Joly, H. I., Leclerc, C., Louafi, S., Martin, P., Massol, F., McGuire, S., McKey, D., Padoch, C., Soler, C., Thomas, M., and Tramontini, S. 2013. Seed exchange networks for agrobiodiversity conservation. A review. Agron. Sustain. Dev. 33:151-175.

Pautasso, M., Doring, T. F., Garbelotto, M., Pellis, L., and Jeger, M. J. 2012. Impacts of climate change on plant diseases-opinions and trends. Eur. J. Plant Pathol. 133:295-313.

Poland, J. 2015. Breeding-assisted genomics. Curr. Opin. Plant Biol. 24:119-124.
Pray, C. E., and Fuglie, K. O. 2015. Agricultural research by the private sector. Annu. Rev. Resour. Econ. 7:399-424.

Puettmann, K. J., Messier, C., and Coates, K. D. 2013. Managing forests as complex adaptive systems: Introductory concepts and applications. Pages 3-16 in: Managing Forests as Complex Adaptive Systems: Building Resilience to the Challenge of Global Change. C. Messier, K. J. Puettmann, and K. D. Coates, eds. Routledge, London.

Rao, Y., Li, Y., and Qian, Q. 2014. Recent progress on molecular breeding of rice in China. Plant Cell Rep. 33:551-564.

R Core Team. 2017. R: A Language and Environment for Statistical Computing. R Foundation for Statistical Computing, Vienna.

Renkow, M., and Byerlee, D. 2010. The impacts of CGIAR research: A review of recent evidence. Food Policy 35:391-402.

Ribaut, J., De Vicente, M., and Delannay, X. 2010. Molecular breeding in developing countries: Challenges and perspectives. Curr. Opin. Plant Biol. 13:213-218.

Rivers, J., Warthmann, N., Pogson, B. J., and Borevitz, J. O. 2015. Genomic breeding for food, environment and livelihoods. Food Secur. 7:375-382.

Robins, G., Pattison, P., Kalish, Y., and Lusher, D. 2007. An introduction to exponential random graph $\left(\mathrm{p}^{*}\right)$ models for social networks. Soc. Networks 29:173-191.

Rodewald, J., and Trognitz, B. 2013. Solanum resistance genes against Phytophthora infestans and their corresponding avirulence genes. Mol. Plant Pathol. 14:740-757.

Sanatkar, M. R., Scoglio, C., Natarajan, B., Isard, S., and Garrett, K. A. 2015. History, epidemic evolution, and model burn-in for a network of annual invasion: Soybean rust. Phytopathology 105:947-955.

Scheffer, M., Carpenter, S. R., Lenton, T. M., Bascompte, J., Brock, W., Dakos, V., van de Koppel, J., van de Leemput, I. A., Levin, S. A., van Nes, E. H., Pascual, M., and Vandermeer, J. 2012. Anticipating critical transitions. Science 338:344-348.

Selisana, S. M., Yanoria, M. J., Quime, B., Chaipanya, C., Lu, G., Opulencia, R., Wang, G.-L., Mitchell, T., Correll, J., Talbot, N., Leung, H., and Zhou, B. 2017. Avirulence $(A V R)$ gene-based diagnosis complements existing pathogen surveillance tools for effective deployment of resistance $(R)$ genes against rice blast disease. Phytopathology 107:711-720.

Shaw, M. W., and Pautasso, M. 2014. Networks and plant disease management: Concepts and applications. Annu. Rev. Phytopathol. 52:477-493.

Singh, R. P., Hodson, D. P., Jin, Y., Lagudah, E. S., Ayliffe, M. A., Bhavani, S., Rouse, M. N., Pretorius, Z. A., Szabo, L. J., and Huerta-Espino, J. 2015. Emergence and spread of new races of wheat stem rust fungus: Continued threat to food security and prospects of genetic control. Phytopathology 105:872-884.

Skelsey, P., Rossing, W. A. H., Kessel, G. J. T., Powell, J., and van der Werf, W. 2005. Influence of host diversity on development of epidemics: An evaluation and elaboration of mixture theory. Phytopathology 95:328-338.

Smale, M., and Day-Rubenstein, K. 2002. The demand for crop genetic resources: International use of the US National Plant Germplasm System. World Dev. 30:1639-1655.

Spielman, D. J., Ekboir, J., and Davis, K. 2009. The art and science of innovation systems inquiry: Applications to sub-Saharan African agriculture. Technol. Soc. 31:399-405.

Sutrave, S., Scoglio, C., Isard, S. A., Hutchinson, J. M. S., and Garrett, K. A. 2012. Identifying highly connected counties compensates for resource limitations when evaluating national spread of an invasive pathogen. PLoS ONE 7:e37793.

Thomas-Sharma, S., Abdurahman, A., Ali, S., Andrade-Piedra, J., Bao, S., Charkowski, A., Crook, D., Kadian, M., Kromann, P., Struik, P., Torrance, L., Garrett, K. A., and Forbes, G. A. 2016. Seed degeneration in potato: The need for an integrated seed health strategy to mitigate the problem in developing countries. Plant Pathol. 65:3-16.

Thomas-Sharma, S., Andrade-Piedra, J., Carvajal Yepes, M., Hernandez Nopsa, J. F., Jeger, M. J., Jones, R. A. C., Kromann, P., Legg, J. P., Yuen, J., Forbes, G. A., and Garrett, K. A. 2017. A risk assessment framework for seed degeneration: Informing an integrated seed health strategy for vegetatively propagated crops. Phytopathology. 107:1123-1135.

Thormann, I., Fiorino, E., Halewood, M., and Engels, J. M. M. 2015. Plant genetic resources collections and associated information as a baseline resource for genetic diversity studies: An assessment of the IBPGR-supported collections. Genet. Resour. Crop Evol. 62:1279-1293.

Wang, H. L., Cui, X. Y., Wang, X. W., Liu, S. S., Zhang, Z. H., and Zhou, X. P. 2015. First report of Sri Lankan cassava mosaic virus infecting cassava in Cambodia. Plant Dis. 100:1029.

Westengen, O. T., Jeppson, S., and Guarino, L. 2013. Global ex-situ crop diversity conservation and the Svalbard Global Seed Vault: Assessing the current status. PLoS ONE 8:e64146. doi:10.1371/journal.pone.0064146

Zhang, Q. 2007. Strategies for developing green super rice. Proc. Natl. Acad. Sci. USA 104:16402-16409.

Zhu, S., Vossen, J. H., Bergervoet, M., Nijenhuis, M., Kodde, L., Kessel, G. J., Vleeshouwers, V., Visser, R. G., and Jacobsen, E. 2015. An updated conventional- and a novel GM potato late blight $R$ gene differential set for virulence monitoring of Phytophthora infestans. Euphytica 202:219-234. 